\title{
Procedure Established by Law, Right to Privacy and Investigative Powers of State: An Appraisal
}

\author{
Rajamanickam Srinivasan*
}

\begin{abstract}
Indian Constitution as we know, is the lengthiest written Constitution in the world. The architects of this stellar monument drew inputs and inspiration from the Constitutions of USA, Australia, Great Britain, Canada, Ireland, France, Germany and Japan. In particular, Part III Fundamental Rights was inspired by the concept of fundamental rights enshrined in the American Constitution. An interesting contrast though is the Indian architects' (especially Sir BN Rau) rejection of the Due Process clause that was introduced by the $5^{\text {th }}$ Amendment to the American Constitution. Instead, drawing from the Japanese, Procedure Established by Law was incorporated when it came to protecting individual citizens' Right to Life and Liberty from arbitrary actions of the State.

In the eight decades after Independence, the Supreme Court of India has expanded and concretized the concept of Procedure Established by law in a manner that is a shining example for protection of human rights everywhere. Juridical principles established by the Apex Court such as Test of Reasonableness play an important role in determining the validity of actions by law enforcement agencies. This paper attempts to compare the Indian Constitutional provisions with appropriate case laws and one of America's oft-cited Rochin's Case in which investigative powers of the state intruded into individual' privacy challenging 'Due Process clause' seriously.
\end{abstract}

Keywords: Constitution, Human Rights, Fundamental Rights, Right to Privacy, Investigative Powers of State, Medical Examination of Accused, Procedure Established by Law, Society and Law

* Dr Rajamanickam Srinivasan is an Independent Researcher. 


\section{Procedure Established by Law, Right to Privacy and Investigative Powers of State: An Appraisal}

\section{Introduction}

In the annals of contemporary judicial history, a theme often found resonating with intense intellectual debate revolves around "due process" and "procedure established by law". Civilized nations that claim to abide by International Human Rights Law regime find their academia and learned judges crossing intellectual swords over the interpretations of both the above principles.

In the aftermath of the reprehensible Holocaust during World War II, nations big and small realized that protection of individual freedoms and liberties from the depredations of the State is fundamental to civilized governance in a free world. The United Nations Charter adopted on $26^{\text {th }}$ June 1945 , unambiguously stated in its Preamble ${ }^{\mathrm{i}}$ :

"to reaffirm faith in fundamental human rights, in the dignity and worth of the human person, in the equal rights of men and women and of nations large and small, and

to establish conditions under which justice and respect for the obligations arising from treaties and other sources of international law can be maintained.."

Further, on the $10^{\text {th }}$ of December 1945, the Universal Declaration of Human Rights (UDHR) was adopted. UDHR was even more explicit ${ }^{\mathrm{ii}}$ :

Whereas disregard and contempt for human rights have resulted in barbarous acts which have outraged the conscience of mankind, and the advent of a world in which human beings shall enjoy freedom of speech and belief and freedom from fear and want has been proclaimed as the highest aspiration of the common people....

\section{Article 3.}

Everyone has the right to life, liberty and security of person. 
Under Article 12 of UDHR, a firm judicial principle was also established, when it stated:

Article 12.

No one shall be subjected to arbitrary interference with his privacy, family, home or correspondence, nor to attacks upon his honour and reputation. Everyone has the right to the protection of the law against such interference or attacks.

Colonial Rule ended across the globe after WW II. The Nuremberg Trials that convicted Nazi military officials for crimes against humanity provided the impetus to the newly independent countries towards formulating Constitutional guarentees to protect people from wanton infringement into their personal liberties. Amongst these nations, India was most important owing to the stellar Gandhian principles on which its independence was won from British Rule. The Indian Constituent Assembly tasked with drafting a new constitution, therefore set some of the brilliant minds on the question of fundamental freedoms. The primary task in this dimension fell on Dr BN Rau, an eminent constitutional law expert himself. Identifying fundamental freedoms to be ensured to citizens in a country that struggled to obtain independence from foreign rule was not as difficult in comparison with the monumental question 'how to secure the rights from an infringing state? The answer came from examining two judicial approaches found in the Constitution of United States and Japan.

In 1791, US adopted the Fifth Amendment to its Constitution as part of the Bill of Rights. In essence, the Amendment read ${ }^{\text {iii. }}$

No person shall be held to answer for a capital, or otherwise infamous crime, unless on a presentment or indictment of a Grand Jury, except in cases arising in the land or naval forces, or in the Militia, when in actual service in time of War or public danger; nor shall any person be subject for the same offence to be twice put in jeopardy of life or limb; nor shall be compelled in any criminal case to be a witness against himself, nor be deprived of life, liberty, or property, without due process of law; nor shall private property be taken for public use, without just compensation. 
From the time it was introduced, a number of important judgments and debates emerged raising highly pertinent questions like what is due process and substantive due process. When is the process due? When is the procedure due?

Revolving primarily around the judgments in Goldberg v. Kelly, Mathews v. Eldridge and the guidelines set by Judge Henry Friendly, a set of factors were identified that would satisfy the questions a court may seek while investigating State action versus individual freedom. The most fundamental and problematic issue in the 'due process' of due processes however remained that of distinguishing between Rights and Privileges ${ }^{\text {iv }}$ (Strauss, n.d). This problem, stated otherwise, rested on judicial interpretation.

The Japanese Constitution adopted in 1946 on the other hand, proclaimed under Article $31^{\mathrm{v}}$ :

- Article 31.No person shall be deprived of life or liberty, nor shall any other criminal penalty be imposed, except according to procedure established by law.

The Japanese Constitutional discourses held up the view that the state's objective in curtailing individual liberties cannot be a good enough justification for the curtailment of individual liberties, when constitutional guarantees on fundamental rights are infringed through a process not sanctioned in law ${ }^{\mathrm{vi}}$.

The drafters of Indian Constitution initially decided to incorporate the American Due Process clause under Article 15. But the Drafting committee suggested the substitution of the expression "except according to procedure established by law" for the words "without due process of law", by giving their own reasons. Ultimately suggestions of Drafting committee prevailed over constituent Assembly. This change was the result of a discussion which the constitutional adviser Sir B.N. Rau held with Mr. Justice Frankfurter of the U.S. Supreme Court ${ }^{\mathrm{vii}}$.

This paper looks at the provisions of the Indian Constitution, discusses the merits of 'procedure established by law' over 'due process of law' in the light of its provisions and relevant International law instruments. Specifically, the paper will deal with the questions in succeeding paragraph. 


\section{Quintessential Questions}

"This is conduct that shocks the conscience. Illegally breaking into the privacy of the petitioner, the struggle to open his mouth and remove what was there, the forcible extraction of his stomach's contents - this course of proceeding by agents of government to obtain evidence is bound to offend even hardened sensibilities. They are methods too close to the rack and the screw to permit of constitutional differentiation".

These were the words of Justice Frankfurter (in Rochin v. Californiaviii) pronouncing his judicial verdict, quoted by Prof. Seth F. Kreimer ${ }^{\text {ix }}$ while debating constitutional validity of torture against terrorist suspects. Needless to say the foundation for the argument itself arises from the conviction that human rights cannot be prejudicial and doled out in preferential quota to the citizens. Unless every citizen enjoys them, the very foundation of democracy will become hollow. A very basic question that arises however is whether the Due Process clause enshrined in American Constitution leaves adequate scope to protect the individual liberties while at the same time allowing the State to exercise its rights to investigate a crime against society? The judicial dilemma in America was concisely expressed by Justice Frankfurter himself in the following words:

To rely on a tidy formula for the easy determination of what is a fundamental right for purposes of legal enforcement may satisfy a longing for certainty, but ignores the movements of a free society. It belittles the scale of the conception of due process. The real clue to the problem confronting the judiciary in the application of the Due Process Clause is not to ask where the line is once and for all to be drawn, but to recognize that it is for the Court to draw it by the gradual and empiric process of "inclusion and exclusion."

The Indian Constitution having adopted the principle of Procedure Established by Law, are the courts in India able to address the stated judicial dilemma in a manner that justifies its preference of this principle over Due Process? 
The answer to this question is discussed in this chapter based on decided cases of the Supreme Court of India and inferences drawn from them. The ensuing discussion is limited to questions that emanate from the portion of judicial verdict quoted above and is not meant as a critique of Rochin's case per se. The scope is to examine the Constitutional and Statutory provisions on the following:

(a) Right to privacy of suspects during police investigations

(b) 'Force' in relation to medical examination of suspects on the request of investigating police officer.

In order to arrive at some conclusions, the provisions of the Indian Constitution will be examined first.

\section{Indian Constitutional Provisions on Fundamental Rights}

\section{Article - 21}

"No person shall be deprived of his life or personal liberty except by the procedure established by law".

The article does not refer to due process of law as prevailing in US constitution (The V th Amendment). It only says procedure established by law and thereby places the legislature in a more important position vis-à-vis judiciary. In Gopalan's case ${ }^{\mathrm{xi}}$ the Supreme Court held that the constitution embodies the English concept of personal liberty and not due process. Therefore if a competent legislature makes a law that a person may be deprived of life and personal liberty in certain circumstances or in certain conditions, the validity of law cannot be questioned on the ground that the law is unfair, unjust or unreasonable.

In Maneka Gandhi Vs UoI ${ }^{\mathrm{xii}}$ Supreme Court in a landmark judgment overruled this earlier decision and declared that Art 21 and Art 19 (Right to Freedom) are complementary in nature and right to travel abroad is a fundamental right. In addition following rights are held to be covered under Article 21. 
(i) Right to live with human dignity ${ }^{x i i i}$

(ii) Right to livelihood because the easiest way to deprive a person of his life is to deprive him of his means of livelihood ${ }^{\mathrm{xiv}}$

(iii) Right to shelter ${ }^{\mathrm{xv}}$

(iv) Right to privacy ${ }^{\mathrm{xvi}}$

(v) Right against inhuman treatment - i.e. custodial violence ${ }^{\mathrm{xvii}}$

(vi) Right against delay in execution ${ }^{\mathrm{x} v i i}$

(vii) Right against solitary confinement ${ }^{\mathrm{xix}}$

(viii) Right to speedy trail ${ }^{\mathrm{xx}}$

(ix) Right against use of $3^{\text {rd }}$ degree method by police ${ }^{x x i}$

(x) Right against handcuffing ${ }^{x x i i}$

(xi) Right against illegal arrest ${ }^{\text {xxiii }}$

This judgment brought the focus on the reasonableness of the restrictions on individual liberties imposed by the 'procedure established by law'. It was apparent that the intent of the legislature in providing for a restrictive procedure was considered reasonable and in furtherance of the needs of the society to protect its larger interest and social order. Thus, while upholding the legislation per se, the Court subjected the procedure to the litmus test of reasonableness.

\section{Individual Right v. Society}

The makers of the Indian Constitution were conspicuous in omitting the 'due process clause' of the Fifth Amendment, though Indian constitution extensively absorbed the underlying principles of the US and Irish Constitutions. While commenting on the Indian omission of the due process clause the very learned Justice Felix Frankfurter said,

"...They (Indian Constitution makers) have rejected it in conspicuous instances after thorough consideration of our judicial history of the 'due process'..." xxiv 
It is recognized that individual is important to the State and that protection of his fundamental rights to enable him to enjoy and exploit his life to the full is the basic duty of the State. The privileges extended to an accused person are a corollary of the common law that an accused is presumed to be innocent unless proved guilty. The protection afforded to the individual under this provision is not merely in respect of testimonial compulsion in the courtroom, but it also extends to any compulsory process for production of documents that are likely to support the prosecution case against him.

The question here is, are the liberties to an individual inviolable? In the context of crime, it is reasonable to presume that any person who commits any act or omission that deprives another of his life or liberty or is 'shocking the conscience of the society', does so not due to ignorance, but by deliberation. Since his intention and volition to commit or omit such an act (though will have to stand judicial scrutiny) gives rise to the belief that such individual is bound to resist the 'due process' of investigation under the cloak of and pain/injury to privacy or personal liberties. Then how do we ensure the rule of law and bring the offenders to book? Can the 'due process' clause be permitted to stand in the way of police investigations and obtaining of evidence to prove the guilty?

Though the Indian Constitution has not adopted the 'due process' clause, Article 21 affords ample scope for its application and enjoins judicial scrutiny to protect an individual from State abuse. The understanding of the need to afford dignity as fundamental to the enjoyment of human rights is ingrained in the constitutional diktats under Art 21. However, when viewed from the perspective that though individual is the basic unit of the society, existence of peace, good order and morality in any society necessitates that there cannot be absolute rights given to an individual which could endanger the larger interests of the society of which he forms but a part. Elaborating on this issue, the Supreme Court of India, in Zahira Habibulla H. Sheikh v. State of Gujarat ${ }^{\mathrm{xxv}}$ held:

"it will not be correct to say that it is only the accused who must be fairly dealt with. That would be turning Nelson's eyes to the needs of the society at large and the victims or their family members and relatives. Each one has an inbuilt right to 
be dealt with fairly in a criminal trial. Denial of fair trial is as much injustice to the accused as to the victim and the society"

The sanctity and extent that must be afforded to rights of an individual vis a vis the social, moral and physical wellbeing of the society has always been a dominant concern for Courts and international covenants on human rights. In this respect, the Universal Declaration of Human Rights 1948 contains a general limitation clause within Article 29 (2) ${ }^{\mathrm{xxvi}}$ :

"In the exercise of his rights and freedoms, everyone shall be subject only to such limitations as are determined by law solely for the purpose of securing due recognition and respect for the rights and freedoms of others and of meeting the just requirements of morality, public order and the general welfare in a democratic society."

The International Convention on Civil and Political Rights (to which India is a signatory) that followed the above declaration in 1966 contains $^{\text {xxvii. }}$

\section{Article 7}

No one shall be subjected to torture or to cruel, inhuman or degrading treatment or punishment. In particular, no one shall be subjected without his free consent to medical or scientific experimentation.

\section{Article 9}

Everyone has the right to liberty and security of person. No one shall be subjected to arbitrary arrest or detention. No one shall be deprived of his liberty except on such grounds and in accordance with such procedure as are established by law.

\section{Article 10}

All persons deprived of their liberty shall be treated with humanity and with respect for the inherent dignity of the human person. 


\section{Article 17}

No one shall be subjected to arbitrary or unlawful interference with his privacy, family, home or correspondence, nor to unlawful attacks on his honour and reputation.

If position of law were so, the questions to be considered now are (academically, on the same Rochin's case): is drug peddling to be considered as reprehensible to the sensibilities of the society? If so, should the offenders be categorized as criminals? Then, should the society, through appropriate law, provide for prosecuting the offender and punish him for offending the sensibilities and moral values of the society?

It is presumed that in all societies across the continents, answers for all the above are in the affirmative. Then, how does the police obtain evidence against him without an affront to the 'due process' clause, especially when he decides not to volunteer evidence? If an offenders' privacy and liberty are paramount and their violation 'shocking to the judicial conscience', how to uphold the rule of law in the society? Will it not deliver the entire judicial system to ransom in the hands of few criminals and their lawyers who 'know' how to wrap up society's quest for justice in carefully couched words of the law? It is but obvious that the answer lies in restricting the rights of the individual to enable investigation and judicial scrutiny of his actions in order to bring him to justice.

\section{Curtailing Individual Liberties: Test of Reasonableness}

The right to personal liberties cannot be unbounded. In any ordained and structured society, the object of criminal justice is substantially different from that of civil justice. While in the civil process, an individual seeks to redress the violations of his individual rights; criminal justice system seeks to remedy the wrongs that the society, through law established, perceives as done against it (despite the fact that the victim is an individual). An interesting contrary view was voiced in the Criminal Law journal in $1998^{\text {xxviii }}$ that the police, prosecution and the courts are concerned with the rights of the criminal and are 
largely unaffected by the plight of the victim, because the criminal justice system's primary objectives are societal in nature!

Art. 21 prohibits the denial of individual life or liberty, except by procedure established by law. It is worthwhile to dwell upon the import of 'procedure established by law' to understand its effect of individual liberties. Courts in India have interpreted this 'procedure' as wide enough to cover the entire process by which the deprivation is effected, not merely to include the adjectival but also the substantive part of law. Take the example of preventive detention. If a person is placed under preventive detention on a ground other than those set out in the law, the preventive detention would obviously be not according to the procedure established by law, because the procedure set out by law prescribes certain conditions under which alone such a detention can be resorted to. If those grounds do not exist, then the detention would be in violation of Art 21. In Bachan Singh v. State of Punjab, the Supreme Court provided an important dimension to 'procedure established by law' by stating, "Every facet of law that deprives a person of his life or personal liberty would, therefore, have to stand the test of reasonableness, fairness and justice in order to be beyond the inhibition of Art 21"xxix which is also implied by the 'due process' clause. Such constraints as are placed on an individual, needless to say, ought to be minimal and cannot exceed the constraints of the particular situation, either in nature or in duration. In Rupinder Sigh Sodhi v. UOI, the above stand was further amplified when the Apex Court said, "Above all, they cannot be used as engines of oppression, persecution, harassment or the like. The sanctity of the person and of privacy has to be maintained at all costs and that cannot be violated under the guise of maintenance of law and order"xxx

Though the makers of the Indian Constitution deliberately abstained from including the 'due process' clause of the American constitution, in construing the permissible restrictions on the freedoms guaranteed by the constitution, the Supreme Court of India has, as a matter of construction, given effect to the same considerations that weighed with the Supreme Court of America while applying the 'due process' clause and the doctrine of the police power. Apparently, the question as to whether the restrictions imposed by law are reasonable or not is subject to examinations by the court by an objective test ${ }^{\mathrm{xxxi}}$ Laying 
down the foundations for the test of reasonableness the learned Chief Justice, Mr. Patanjali Shastri, said ${ }^{x x i i}$ :

"It is important in this context to bear in mind that the test of reasonableness, wherever prescribed, should be applied to each individual statute impugned, and no abstract standard, or general pattern, of reasonable can be laid down as applicable to all cases. The nature of the right alleged to have been infringed, the underlying purpose of the restrictions imposed, the extent and urgency of the evil sought to be remedied thereby, the disproportion of the imposition, the prevailing conditions at that time, should all enter into the judicial verdict. In evaluating such elusive factors and forming their own conception of what is reasonable, in all the circumstances of a given case, it is inevitable that the social philosophy and the scale of values of the Judges participating in the decision should play an important part, and the limit to their interference with the legislative judgment in such cases can only be dictated by their sense of responsibility and self restraint and the sobering reflection that the Constitution is meant not only for people of their way of thinking but for all, and that the majority of the elected representatives of the people have, in authorizing the imposition of the restrictions, consider them to be reasonable"

Inalienable right to life with dignity and the pursuit of all necessary means to this end cannot be deprived to any individual, except when such individual has to stand the scrutiny of established law for an act or omission that infringes on the liberties and rights of all other members of the society. Under these circumstances, the need to curtail individuals' rights so as to subject him fruitfully to judicial scrutiny has the sanction of Constitutions and Courts across the world. Even then, no arbitrary and oppressive measures and procedures are accepted except those that stand the test of reasonableness. A comparison with the mandates of Canadian and New Zealand Courts on the 'reasonableness' of restrictions would reveal that the concept of individual liberty being subject to social needs is universally acceptable. 
In order to determine reasonableness, Canadian and New Zealand Courts have both developed sets of principles. A Full Court of the High Court in Solicitor-General v Radio New Zealand Ltd discussed the relevant authorities ${ }^{\text {xxxiii }}$ It was stated there that the starting point in applying the substantive test is the Supreme Court case of $\mathrm{R} v$ Oakes $^{\mathrm{xxxiv}}$ where the Court set out a detailed test. In an early formulation of the applicable test, the Court said that a limit will be reasonable and demonstrably justified in a free and democratic society if:

(i) the objective sought to be achieved by the limitation at hand must relate to concerns which are pressing and substantial in a free and democratic society; and

(ii) the means utilized must be proportional or appropriate to the objective. In this connection there are three aspects:

- the limiting measures must be carefully designed or rationally connected to the objective;

- $\quad$ they must impair the right or freedom as little as possible;

- $\quad$ their effects must not so severely curtail individual or group rights that the objective of the limitation, albeit important, is nevertheless outweighed by the restriction of the right or freedom concerned. ${ }^{\mathrm{xxv}}$

The New Zealand High Court in SG v Radio NZ Ltd rephrased the test slightly as follows, although this clearly follows the two-stage approach adopted by the Supreme Court:

"...To establish that the limit is both reasonable and demonstrably justified in a free and a democratic society the law creating the limit on the right of freedom must have an objective of sufficient importance to warrant overriding a constitutionally protected right or freedom. ...The means chosen by the law to achieve the objective must be proportional and appropriate to be objective. ... To meet the requirement of the proportionality test there are three components. 
First, the limiting measures or the law must be designed to achieve the objective not being arbitrary, unfair or based on irrational considerations. This is described as being rationally connected to the objective. Second, the measures or the law should impair as little as possible the right or freedom. Third, there must be a proportionality between the effects of the measures or the law responsible for limiting the right or freedom and the objective. The law which restricts the right must not be so severe or so broad in application as to outweigh the objective." xxxvi

It is as well to remember Judge Hand when he said, "liberty lies in the hearts of men and women, when it dies there, no Constitution, no law, and no Court can even do much to help

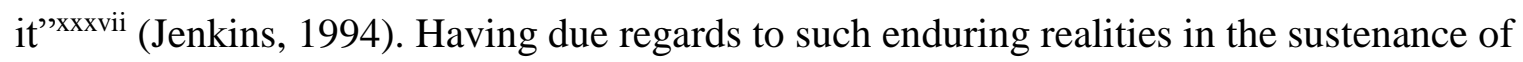
orderly society, the Constitution also guarantees certain inherent rights to the accused to protect his basic rights, when it is subjected to unreasonable and oppressive restrictions. Art. 20 of the Indian Constitution provides that:

(a) No person shall be prosecuted and punished for the same offence more than once.

(b) No person accused of any offence shall be compelled to be a witness against himself.

The protection afforded to the individual under these provisions is not merely in respect of testimonial compulsion in the courtroom, but it also extends to any compulsory process for production of documents that are likely to support the prosecution case against him.

\section{Procedure Established By Law: Is It Sacrosanct?}

An issue that must be considered at this juncture is whether so long as the procedure established by law is complied with, an accused can be subjected to restrictions granted by the procedure wantonly, without actually bringing him to justice? While deliberating the reasonableness of legislative discrimination to give effect to the principle of equality before law enshrined in Article 14 of the Constitution, in the case of R.K.Dalmia v. Justice Tendulkar ${ }^{\text {xxxviii }}$, Mr. Justice Das of the Supreme Court spelt out a guiding principle that 
'the legislature is free to recognize degrees of harm and may confine its restriction to those cases where the need is deemed clearest However, the legislature is not free to prescribe such procedure that would be unreasonable and in excess of the object of the legislation as a whole. The infringement into the constitutionally guaranteed freedom of life (with dignity) and liberties, merely because a legislative procedure/quasi-judicial authority prescribes it, would be violative of the fundamental rights and therefore against the Constitution'. In two of the hallmark judgments in Menaka Gandhi v.Union of India ${ }^{\text {xxxix }}$ and Kharak Singh v. State of U.P. ${ }^{\mathrm{xl}}$, the Supreme Court of India made it absolutely clear that right to live is not merely confined to physical existence but it includes within its ambit the right to live with 'human dignity'. Thus any procedure established by law, which imposes restrictions that are not reasonable, and are oppressive to and beyond the objective of the legislature in laying down the impugned procedure will be liable to be 'shocking the judicial conscience'. In Kharak Singh's case the Court made it clear that unauthorized intrusion into a person's home and disturbances caused to him are in violation of his personal liberty. In fact, the basic facts and principles underlying Kharak Singh's case may well apply to Rochin. Kharak Singh was charged in a decoity case but was released, as there was no evidence against him. The Police opened a history-sheet against him and kept surveillance on his house and activities. This included secret picketing of his house, domiciliary visits at nights and verification of his activities and movements. The Supreme Court held that the domiciliary visits are a violation of his personal liberty in the form of inhibition of his ordinary enjoyment of life with dignity. The Court struck down the Police Regulation authorizing such domiciliary visits, as violative of Art 21.

In the case of Rochin, though the exact process adopted by deputies was possibly sufficient to attract the 'due process' clause, the questions still remain whether Deputies entering a premise on suspicion of a cognizable offence, carrying out a search including on the person of accused and having him medically examined to elicit evidence would fall beyond the purview of 'reasonableness' in conformity with 'procedure established by law'? 


\section{Rochin through the Eyes of Indian Criminal Procedure Code}

In India, The Criminal Procedure Code ( $\mathrm{Cr} \mathrm{PC}$ ) is the penal statute that provides for the procedure adopted in investigation and bringing the offenders to justice. It is to be seen whether the procedure set out in Cr PC for cases involving facts akin to Rochin will stand the test of reasonableness and constitutionally valid 'procedure prescribed'. Before the relevant procedure is considered, we must study the object of this Code, so as to examine whether it meets the Supreme Court's diktat of reasonableness. The Cr PC (Act 2 of 1974) is an act to consolidate and amend the law relating to criminal procedure. It being a penal statute providing for punishment and prevention of offences against the substantive criminal law must be construed strictly. This means in case of ambiguity, the statute should be construed in favour of the subject. This further means that unless penalties are imposed in clear terms they are not enforceable. But care should be taken to see that the words of ambiguous meaning should be interpreted in a broad and liberal sense so that they do not become traps for honest, unlearned and unwary men ${ }^{x l i}$

Drawing from the Supreme Court's interpretation in Iqbal v. State of Maharashtraxliin which it said, "It is the procedure that spells much of the difference between rule of law and the rule of whim and caprice", we may derive the intention and object of the statute as the following:

(a) That it is the procedure for punishment and prevention of offences against Substantive criminal law.

(b) That the procedures prescribed are to be interpreted so as to favour the accused, in case of any ambiguity.

(c) That the interpretation of the procedures should not become traps for honest men.

Seen in this light, one may presume that the legislature while enacting this statute was aware that procedures prescribed, when exercised in the context of police powers, were potent with the scope for abuse and thereby may result in the harassment, denial and 
unreasonable restriction of individual rights. It is clear that the legislative intent against the Constitutional provisions relating to individual rights or oppression of the innocent was deliberately and conspicuously excluded, by the plain reading of the object of Cr PC. In a democracy, the legislated statutes are but the reflections of the aspirations of the people as to the kind of society that they intend to create through such statutes. It is also to be kept in mind that as against civil liberties obtained through civil process for individuals, the State seeks to establish uniform law and code of conduct for peace and good order in the society. That is why criminal offences relating to individuals are construed as offences against the State since State is the repository of people's aspirations and the means to achieve them. Thus, when prescribing a procedure that may tantamount to deprivation of civil liberties, the legislature tends to sheath the provisions with as much caution as is practicable to achieve the objective of 'prevention of crime'.

\section{Intrusion of Privacy}

Section 47 of the Cr PC (Search of Place Entered by Person Sought to Be Arrested) ${ }^{x \text { liii }}$ provides that:

(1) If any person acting under a warrant of arrest, or any police officer having authority to arrest, has reason to believe that the person to be arrested has entered into, or is within, any place, any person residing in, or being in charge of, such place shall, on demand of such person acting as aforesaid or such police officer, allow him free ingress thereto, and afford all reasonable facilities for a search therein.

(2) If ingress to such place cannot be obtained under sub section (1), it shall be lawful in any case for a person acting under a warrant and in any case in which a warrant may issue, but cannot be obtained without affording the person to be arrested an opportunity to escape, for a police to enter such place and search therein, and in order to effect an entrance into such place, to break open any outer or inner door or window of any house or place, whether that of the person to be arrested or of any other 
person, if after notification of his authority and purpose, and demand of admittance duly made, he cannot otherwise obtain admittance.

As may be inferred, the provision un-ambiguously vests the power to enter and search a place by police, if necessary by use of force ${ }^{x l i v}$ so long as the occupant has been duly notified of the intention to enter and search ${ }^{\mathrm{xlv}}$ with or without warrant. In the circumstances leading to the arrest of Rochin, it is presumed that similar procedures would have to be complied with. Under the circumstances of denial of entry, use of force to enter after a verbal caution in suitable words would adequately meet the test of 'reasonableness' under the Constitution. Unlike Kharak Singh's case where the domiciliary visits were made on him at untimely hours with a mere objective of confirming his availability at his home (and not committing any decoity elsewhere), there was definite information of possession of narcotics and Rochin was wanted for drug peddling. The differences in the 'privacy' element in both the cases are all too different.

\section{Medical Examination of Accused}

Section 53 of Cr PC (Examination of Accused by Medical Practitioner at the Request of Police Officer $)^{\mathrm{xlvi}}$ provides that:

(1) When a person is arrested on a charge of committing an offence of such a nature and alleged to have been committed under such circumstances that there are reasonable grounds for believing that an examination of his person will afford evidence as to the commission of an offence, it shall be lawful for a registered medical practitioner, acting at the request of a police officer not below the rank of sub-inspector, and for any person acting in good faith in his aid and under his direction, to make such an examination of the person arrested as is reasonably necessary in order to ascertain the facts which may afford such evidence, and to use such force as is reasonably necessary for that purpose. 
It is important to understand that the legislature was aware of the import of this provision and still empowered the police to do so in the interest of 'fairness' to the cause of the society and to prevent the accused from taking recourse to fundamental rights to obstruct the course of investigations. In the words of the Bill of 1970 that introduced this amendment to $\mathrm{Cr} \mathrm{PC}$, “To facilitate effective investigation, provision has been made authorizing an examination of arrested person by a medical practitioner, if from the nature of the alleged offence or the circumstances under which it was alleged to have been committed there is reasonable ground for believing that an examination of person will afford evidence."xlvii

Strengthening the investigation process, the Supreme Court in Ananth Kumar Naik ${ }^{\text {xlviii }}$ case ruled that though taking of blood or semen may inflict some torture or pain to an accused, Section 53 authorizes it. Even reasonable force can be used to subject the arrested person to medical examination though it may mean discomfort to him. The examination of person on bail and obtaining of his blood group or such other examination as is necessary by 'reasonable' use of force has been held to be constitutional and within the ambit of Section 53.

In the same context, examining the arrested person medically and administering 'logical' medical examination to obtain the evidence essential to prove his guilt is to be construed as reasonable and authorized as per established procedure under the law, so long as they are not disproportionate to the objective of the law and aimed at harassing and inflicting wanton pain on the accused. The words 'it shall be lawful' have also been interpreted as words of permission only and as enabling and empowering words ${ }^{\text {xlix }}$

\section{Police Investigation and Criminal Justice System}

Police investigations are as much part of the criminal justice system as the need of the society to sanction a statute for upholding law and order for the milieu through which every member of the society can pursue his life and realize the fruits of freedom guaranteed to him under the Constitution. The process of investigation, undoubtedly, cannot be above the law if it has to be a tool for achieving the ends of law. At the same time limiting the 
process of investigation to the extent of constraining it within the ethical connotation of law, in most instances, is bound to defeat the purpose of the law itself. Appreciating the importance of unfettered investigative process (not illogical and brutal, of course), the Supreme Court of India ruled ${ }^{1}$

"The investigation of an offence is the field exclusively reserved for the police officers whose powers in that field are unfettered so long as the power to investigate into the cognizable offence is legitimately exercised in strict compliance with the provisions falling under Chapter XII of the Code $(\mathrm{Cr}$ PC) and the Courts are not justified in the track of investigation when the investigating agencies are well within their legal bounds as aforementioned. Indeed, a noticeable feature of the scheme under Chapter XIV of the Code is that a Magistrate is kept in the picture at all stages of the police investigation but he is not authorized to interfere with the actual investigation or to direct the police how that investigation is to be conducted. But if a police officer transgresses the circumscribed limits and improperly and illegally exercises his investigatory powers in breach of any statutory provisions causing serious prejudice to the personal liberty and also property of a citizen, then the Court on being approached by the person aggrieved for the redress of any grievance has to consider the nature and extent of the breach and pass appropriate orders as may be called for without leaving the citizens to the mercy of police echelons since human dignity is a dear value of our Constitution."

In the same breath, the Apex Court was also equally emphatic that:

It can be a guiding principle that as investigation is not the solitary area for judicial scrutiny in a criminal trial, the conclusion of the court in the case cannot be allowed to depend solely on the probity of investigation. It is well settled that even if the investigation is illegal or even suspicious the rest of evidence must be scrutinized independently of the impact of it. Otherwise criminal trial will plummet to the level of the investigating officers ruling 
the roost. The court must have predominance and pre-eminence in criminal trials over the action taken by investigating officers. Criminal justice should not be made the casualty for the wrong committed by the investigating officers in the case ${ }^{\mathrm{li}}$

And further, it ruled that:

The function of the Criminal Courts should not be wasted in picking out the lapses in investigation and by expressing unsavory criticism against investigating officer. If offenders are acquitted only on account of flaws or defects in investigation, the cause of criminal justice becomes the victim. Effort should be made by Courts to see that criminal justice is salvaged despite such defects in investigation. Courts should bear in mind the time constraints of the police officers in the present system, the ill equipped machinery they have to cope with and the traditional apathy of respectable persons to come forward for giving evidence in criminal cases which are realities, the police force have to confront with while conducting investigation in almost every case. Before an investigating officer is imputed with castigating remarks the Courts should not overlook the fact that usually such an officer is not heard in respect of such remarks made against him. The court need make such deprecatory remarks only when it is absolutely necessary in a particular case, and that too by keeping in mind the broad realities indicated above ${ }^{\text {lii }}$

In the light of the views and rulings of the Apex Court read with the Constitutional provisions regarding 'procedure established by law' and its implications on individual liberties, it can be garnered that no system of law sanctioned restrictive and exploitive practices merely to uphold the objective of law in society. Nor were such laws in their zeal to apply moral and ethical standards in a dogmatic sense, intend to allow individuals with scant respect for moral sensibilities of the society to hoodwink the judicial process in the garb of personal liberties. This judicial balancing between individual liberties and procedural means to achieve justice cannot be achieved unless the investigative process is 
afforded reasonable immunity. The interests of justice will be served better when police investigators conscientiously apply their powers to unravel crime and are sensitive to Human Rights issues. As 'correction' than 'punishment' is the need of the hour in most part of the World to bring the erring into mainstream life of the society, the police are under a Constitutional mandate to adopt reasonable and justifiable measures in bringing the accused 'home' to justice.

\section{Conclusion}

Judiciary is an important and vital component of the democracies of the world because it scrutinizes whether the laws enacted by the elected Legislature are indeed just and fair; that they meet the objectives for which such laws have been established and that the procedures established under these laws meet the aspirations of the society in enjoying the fruits of freedom that is so dear to the enlightened humanity. That there can be no freedom without discipline and that discipline, alas, has to be enforced are but facts of life that need no elaborate arguments to support them. It is also a fact that in every society there will always be individuals whose pursuit of their 'freedom' will be at variance with the norms that afford peace, stability and enjoyment of life with dignity by the majority.

But, going by the thumb rule of majority in all democratic processes, it is essential that the law must cater to the inadequacies in bringing the offenders to the book than to let them enjoy the larger benefits of freedom better than the otherwise law-abiding but docile segments of the society. What must shock the judicial conscience are not that one known criminals' sensibilities and liberties have been offended but that the individual had exploited the legal decency to defy the society's larger interests with impunity. While reasonableness of the restrictions imposed by any law must confirm to the guarantees of the Constitution, there should be no hesitation in upholding the social, moral and security needs of the society as paramount and, if need be, above the liberties of a single nonconformist individual who poses a serious threat to the liberties of the society itself, in accordance with the procedure established by law. 
The debate over Due Process of Law and Procedure Established by Law that has occupied the minds of judiciary highlights the dilemma that we face when dealing with heinous crimes accentuated especially in the case of terrorist crimes. The remarkable interpretations of the Supreme Court of India in a number of cases provides an illuminating answer to this problematic question. In making the distinction between rule of law and rule of whim and caprice, we feel that the Apex Court has yet again demonstrated that Hon'ble Felix Frankfurter was right in his opinion that by rejecting the due process clause, the Indian Constitution has facilitated democratic principles of equality before law in a holistic manner. In his own judgment in Wolf v. Colorado, Justice Frankfurter had indirectly validated the Indian principle of procedure established by law.

How far should the law of the land go in protecting the individual liberties where heinous crimes are concerned may perhaps be debated for eternity? However, the successive decisions taken by Indian Supreme Court show that the principle of procedure established by law has been constantly expanded to address concerns that reverberate in these learned debates. By upholding Article 21 as the soul of the Constitution, the Apex Court also has ensured that compulsions of political or executive or even legislative actions cannot erode the bulwark of egalitarian and democratic Constitutional structure on which India rests.

Abbreviations pertaining to Indian Courts and journals used in the paper are:

AIR : All India Reporter, published by All India Reporter Pvt. Ltd., Nagpur, India, which is relied upon by lawyers, students and courts alike.

AIR SCW: All India Reporter Supreme Court Weekly, a weekly digest with summary of Cases decided by Supreme Court of India, published by All India Reporter Pvt. Ltd., Nagpur, India

Cr PC : Criminal Procedure Code, 1974 (and its Amendments)

Cr LJ : Criminal Law Journal, Journal published by All India Reporter Pvt. Ltd., Nagpur, India, which is relied upon by lawyers, students and courts alike.

ILR : Indian Law Reporter 


\section{SCC : Supreme Court Cases \\ SCR : Supreme Court Reporter}

\section{References}

${ }^{i}$ UN. (n.d). United Nations. Retrieved October 06, 2020, from Preamble to UN Charter: https://www.un.org/en/sections/un-charter/preamble/index.html

${ }^{\text {ii }}$ UDHR. (n.d). United Nations. Retrieved October 06, 2020, from Universal Declaration of Human Rights: https://www.un.org/en/universal-declaration-human-rights/index.html

iii US Congress. (n.d). Constitution Annotated. Retrieved August 16, 2020, from Constitution of the United States:

https://constitution.congress.gov/constitution/amendment-5/

iv Strauss, P. (n.d). Legal Information Institute, Cornell University. Retrieved November 25, 2020, from Due Process: https://www.law.cornell.edu/wex/due_process

${ }^{v}$ Govt of Japan. (n.d). Birth of the Constitution of Japan. Retrieved November 06, 2020, from The Constitution of Japan: https://www.ndl.go.jp/constitution/e/etc/c01.html\#s3

${ }^{v i}$ Kawagishi, N. (2003). Digital Commons. Retrieved December 06, 2020, from The Constitution of Japan: An Unfinished Revolution.:

https://digitalcommons.law.yale.edu/cgi/viewcontent.cgi? article=1003\&context=ylsd

${ }^{\text {vii }}$ Quaiyum, A. (1993). PhD Thesis 1992. Retrieved December 06, 2020, from Due Process of Law vis-a-vis Procedure Established by Law:

https://core.ac.uk/download/pdf/144522465.pdf

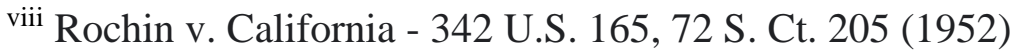

ix Kreimer, Seth F., "Too Close to the Rack and the Screw: Constitutional Constraints on Torture in the War on Terror" (2003). Faculty Scholarship at Penn Law. 1166. https://scholarship.law.upenn.edu/faculty_scholarship/1166

${ }^{x}$ Wolf v. Colorado, 338 U.S. 25 (1949) See:

https://supreme.justia.com/cases/federal/us/338/25/

${ }^{x i}$ A.K. Gopalan v. State of Madras, (1950) S.C.R. 88

${ }^{\text {xii }}$ Maneka Gandhi v. Union of India, AIR 1978 S.C. 597 
xiii And all that goes along with it, namely, adequate nutrition, clothing shelter and facilities for reading, writing \& expressing ourselves in diverse forms, moving freely and mingling with fellow human beings.

xiv In Re Sant Ram v. Unkown (AIR 1960 SC 932, 19603 SCR 499), the Supreme Court had ruled that the right to livelihood would not fall within the expression "life" in Article 21. The Court said:

"The argument that the word "life" in Article 21 of the Constitution includes "livelihood" has only to be rejected. The question of livelihood has not in terms been dealt with by Article 21."

However, when the case of forceful eviction of pavement dwellers by Bombay Municipal Corporation came before it in 1986, (Olga Tellis \& Ors v. Bombay Municipal Corporation \& Ors, 1986 AIR 180, 1985 SCR Supl. (2) 51) the Court observed that the right to livelihood is born out of the right to life, as no person can live without the means of living, which is, their means of livelihood. It said:

"....the question which we have to consider is whether the right to life includes the right to livelihood. We see only one answer to that question, namely, that it does. The sweep of the right to life conferred by Article 21 is wide and far-reaching. It does not mean, merely that life cannot be extinguished or taken away as, for example, by the imposition and execution of the death sentence, except according to procedure established by law. That is but one aspect of the right to life an equally important facet of that right is the right to livelihood because, no person can live without the means of living, that is, the means of livelihood."

${ }^{\mathrm{xv}}$ which include adequate living space, safe \& decent structure, clean surroundings, pure air \& water, electricity \& other civic amenities. See: U.P. Avas Evam Vikas Parishad \& Anr vs Friends Coop. Housing (1996 AIR 114, 1995 SCC Supl. (3) 456) and M/S. Shantistar Builders vs Narayan Khimalal Totame And Ors (AIR 1990 SC 630, (1990) 92 BOMLR 145, JT 1990 (1) SC 106)

${ }^{x v i}$ See Kharak Singh v. State of U.P. discussed in the paper.

xvii India is a signatory to United Nations Convention Against Torture and Other Cruel, Inhuman and Degrading Treatment or Punishment. See Law Commission Report No. 273 at https://lawcommissionofindia.nic.in/reports/Report273.pdf

${ }^{x v i i i}$ If the President does not dispose off any mercy-petition against death sentence for more than 2 years the death sentence will automatically be converted into life sentence.

${ }^{\text {xix }}$ Supreme Court held that solitary confinement is violative of Art. 21 because it deprives the liberty to mix, to mingle and talk with the co-detainees/visitors.

${ }^{x x}$ In Hussainara Khatoon v. State of Bihar which formed the basis of the concept of the Speedy Trial, it was held that where under trial prisoners have been in jail for duration 
longer than prescribed, if convicted, their detention in jail is totally unjustified and in violation to fundamental rights under article 21 . Inordinate delays violates article 21 of the constitution: for more than 11 yrs the trial is pending without any progress for no faults of the accused-petitioner. Expeditious justice is a basic right to everybody and cannot be trampled upon unless any of the parties can be accused of the delay. Delay in trial unnecessarily confers a right upon the accused to apply for bail. Under sec. 482 read with 483 , Cr. P.C lays that every possible measure to be taken to dispose of the case within 6 months from today. No adjournments to be granted until and unless circumstances are beyond the control of judiciary. It is the responsibility of the judiciary to keep a check on under trial prisoners and bring them to trial. Overcrowded courts, inadequate resources, fiscal deficiency cannot be the reasons for deprivation of a person. See: http://www.legalservicesindia.com/article/571/Constitutional-Right-to-Speedy-Trial.html

${ }^{\text {xxi }}$ See Note ix.

xxii Police had to pay Rs. 2000/- for having handcuffed a lawyer. Supreme Court declared that even a prostitute who is of easy virtue has a right to privacy.

xxiii For an interesting analysis, see: Srivastava, B. (1969). RIGHT AGAINST

ARBITRARY ARREST AND DETENTION UNDER ARTICLE 9 OF THE COVENANT AS RECOGNIZED AND PROTECTED UNDER THE INDIAN LAW. Journal of the Indian Law Institute, 11(1), 29-56. Retrieved December 8, 2020, from http://www.jstor.org/stable/43950009

xxiv ' Much of the constitution makers of other countries have drawn upon our experience, it is precisely because they have drawn upon it that they have one and all, abstained from including a "due process" clause. They have rejected it in conspicuous instances after thorough consideration of our judicial history of the 'due process'... It is particularly noteworthy that such was the course of events in framing the Constitution of India. Sir B.N. $\mathrm{Rau}$, one of the most penetrating minds of our time, had a major share in drafting, and for the purpose he made a deep study of the working of the due process clause during his extensive stay here. (Mr. Justice Felix Frankfurter of the Supreme Court of America, in his 'Address on John Marshall and Judicial Function'. Government Under Law: p.24)

${ }^{x x v} 2004$ AIR SCW 2325 (A) : 2004 (4) SCC 153: 2004 (3) Supreme 210: 2004 (4) Scale 375

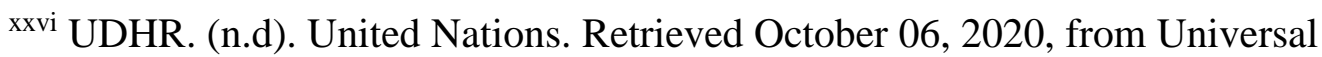
Declaration of Human Rights: https://www.un.org/en/universal-declaration-humanrights/index.html

xxvii See full text of ICCPR at: https://www.ohchr.org/en/professionalinterest/pages/ccpr.aspx

xxviii 1998 Cr LJ, Journal Section at 74. 
${ }^{\text {xxix }}$ Bachan Singh v. State of Punjab, AIR 1982 SC 1325 at 1340.

${ }^{x x x}$ Rupinder Singh Sodhi v. Union of India, AIR 1983 SC 65 at 66.

xxxi "The determination by the legislature of what constitutes a reasonable restriction is not final and conclusive; it is subject to the supervision by this court. In the matter of fundamental rights, the Supreme Court watches and guards the rights guaranteed by the constitution and in exercising its functions it has the power to set aside an act of the Legislature if it is in violation of the freedom guaranteed by the Constitution." Mahajan, $\mathrm{J}$. in Chintaman rao v. State of Madya Pradesh, (1950) S.C.R. 759 at 675; Jyoti Prasad v. The Administrator for The Union Territory of Delhi, (1962) 2 S.C.R. 125.

xxxii State of Madras v. V.G. Row, (1952) S.C.R. 697; State of Uttar Pradesh v. Kaushalya Devi, A.I.R. (1964) S.C.R. 416 at 422.

xxxiii The New Zealand Supreme Court observed, "The conduct that is prohibited is that which creates a "real risk" to the administration of justice, so whether there was any intention to interfere with the administration of justice or whether any harm to the trial actually eventuated is not particularly relevant, given the preventative function of the contempt".

See: http://ip36.publications.lawcom.govt.nz/Chapter+4+-

+Reforming+publication+contempt/Current+law+and+application

xxxiv (1986) 26 DLR (4th) 200.

xxxv That decision was later affirmed and followed by the Supreme Court of Canada in Irwin Toy Ltd v Quebec (Attorney-General) (1989) 58 DLR (4th) 577 and Re A Reference re Public Service Employee Relations Act [1987] 1 SCR 313, 373-374. The latter case was referred to with approval by the NZCA in MOT v Noort; Police v Curran, above n 86, 283. Cases have, however, moved away from requiring limitations to impair rights "as little as possible" (requirement (2) of the proportionality test) to a more flexible test of "as little as reasonably possible".

xxxvi This was subsequently cited with approval in Duff v Communicado Ltd [1996] 2 NZLR 89. Note that in MOT v Noort; Police v Curran, above $n$ 86, (which pre-dates the latter case law) Richardson J said at p.283: "It is worth emphasising too that in principle an abridging inquiry under s 5 will properly involve consideration of all economic, administrative and social implications. In the end it is a matter of weighing (1) the significance in the particular case of the values underlying the Bill of Rights; (2) the importance in the public interest of the intrusion on the particular right protected by the Bill of Rights; (3) the limit sought to be placed on the application of the Bill provision in the particular case; and (4) the effectiveness of the intrusion in protecting the interests put forward to justify those limits." 
xxxvii Jenkins, R. (1994, May 18). Baltimore Sun. Retrieved Decemebr 06, 2020, from Learned Hand and the Spirit of Liberty: https://www.baltimoresun.com/news/bs-xpm1994-05-18-1994138163-story.html

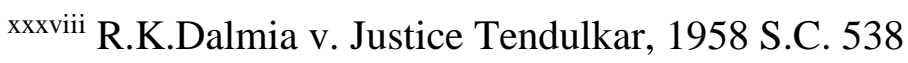

xxxix 1978 AIR 597, 1978 SCR (2) 621

xl 1963 AIR 1295, 1964 SCR (1) 332

xli B.B. Mitra on "Code of Criminal Procedure", Kamal law House, Kolkata, 1998, p.1. As also S.C. Mills Ltd. AIR 1953 SC 278; Sarbananda Sarkar AIR 1969 Cal 474; 1969 Cr LJ 1221; M.V. Joshi v. M.U. Shimpi AIR 1961 SC 1494; (1961) 2 Cr LJ 696.

xlii (1975) 3 SCC 140

xliii See https://indiankanoon.org/doc/249603/

${ }^{\text {xliv }}$ Romesh ILR 41 Cal 350

${ }^{x l v}$ Russell on Crimes, p.745

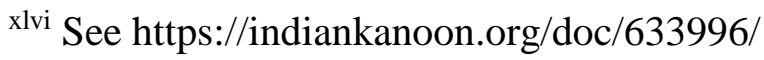

xlvii See Law Commission of India, $37^{\text {th }}$ Report at: https://lawcommissionofindia.nic.in/150/Report37.pdf

xlviii Ananth Kumar Naik 1977 Cr LJ 1797 (AP)

xlix Julius (1880) AC 214, 222, 229, 230.

${ }^{1}$ State of Haryana and others vs. Ch. Bhajan Lal and others, 1992 Cr LJ 527: 1992 AIR (SC) 604: 1992 SCC (Cr) 426.

${ }^{\text {li }}$ State of Karnatka vs K.Yarappa Reddy, JT.1999 (8) S.C. 10

lii State of West Bengal vs Mir Mohammad Omar \& Ors. Etc., JT 2000(9) SC 467 